\title{
Near-shore distribution of Heaviside's (Cephalorhynchus heavisidii) and dusky dolphins (Lagenorhynchus obscurus) at the southern limit of their range in South Africa
}

\author{
S.H. Elwen ${ }^{*}$, M. Thornton ${ }^{2}$, D. Reeb' \& P.B. Best ${ }^{2}$ \\ ${ }^{1}$ Mammal Research Institute, University of Pretoria, Pretoria, 0001 South Africa \\ ${ }^{2}$ Mammal Research Institute, University of Pretoria, 0001 Pretoria \\ c/o Iziko South African Museum, P.O. Box 61, Cape Town, 8000 South Africa \\ Received 3 August 2009. Accepted 11 December 2009
}

\begin{abstract}
Photo-identification surveys over three years along $390 \mathrm{~km}$ of coastline north of Cape Town, revealed that Heaviside's dolphin distribution was consistent between years and higher in areas more exposed to swells and with greater long-term availability of small hake Merluccius capensis (their principal prey). Dusky dolphin sighting rates varied considerably between years, but were generally higher in areas with lower hake availability and sandier shores (mostly straighter coastline). Large groups of 50-200 dusky dolphins were only seen in St Helena Bay, the site of a wind-driven upwelling zone. Heaviside's dolphins were found in shallower, cooler water than dusky dolphins and were more likely to be seen during brighter phases of the moon (when nocturnal light conditions may influence the vertical migration patterns of prey) and in areas of high hake abundance. Near-shore fishing activity was higher in the northern half of the study area and clustered around harbours. Set netting occurred only at Yzerfontein and St Helena Bay, but due to changes in the industry is currently thought to be a low threat to the population. Interactions between Heaviside's and dusky dolphins were usually neutral and sympatry appears to be mediated by differences in overall range and the type and size of prey species taken.
\end{abstract}

Key words: distribution, dusky dolphin, fisheries interactions, Heaviside's dolphin, predator-prey relationships.

\section{INTRODUCTION}

Within the range of most species there is considerable variation in the number and density of animals at a variety of scales (Begon et al. 2005). Marine mammals are no exception and variation in their abundance has been associated with both environmental and biological influences, including depth, sea floor gradient, oceanographic features, predator avoidance and competitive exclusion (Goodall et al. 1995; Tynan 1997; Davis et al. 1998; Elwen \& Best 2003; Hastie et al. 2005; Heithaus \& Dill 2006). The relationships between abundance and covariates may change with the scale of the study, and it is these changes which can illustrate the ecological relationships involved (Benoit-Bird \& Au 2003; Johnston et al. 2005).

Along the west coast of southern Africa, Heaviside's and dusky dolphins are known to be sympatric within the coastal environment, but knowledge of their distribution is currently limited to broad-scale descriptors. Findlay et al.

\footnotetext{
*Author for correspondence. E-mail: simon.elwen@gmail.com
}

(1992) described the general range of Heaviside's dolphins as 'west of Cape Point $\left(18.5^{\circ} \mathrm{E}\right)$... possibly into southern Angola ... all sightings in waters shallower than $200 \mathrm{~m}$, the highest densities being inshore of the $100 \mathrm{~m}$ isobath', and dusky dolphins as 'entirely sympatric but with wider, although not entirely known limits extending to $19^{\circ} \mathrm{E}$ (east of Cape Point into False Bay), northwards into Angola to at least $12^{\circ} \mathrm{S}$ and offshore to at least $500 \mathrm{~m}$ depth and possibly as much as $2000 \mathrm{~m}$ of water'. Such a broad-scale overlap of ranges between potentially competing predators may be more clearly differentiated by habitat selection at finer spatial (Goodall et al. 1995; Heinrich 2006; Parra 2006) or temporal (Thompson et al. 2004) scales. To date, no studies have investigated either the environmental factors influencing niche or habitat selection or the sympatry of Heaviside's and dusky dolphins at finer spatial scales.

The needs of foraging animals are a trade-off between maximizing prey consumption and minimizing risk and energy expenditure, and 
involve a complex interaction of many covariates. The ecological link between physical or oceanographic features and cetacean distribution patterns is frequently their association with prey, which have either themselves been physically aggregated by oceanographic features, or subsequently attracted to aggregations of their own smaller prey (Wolanski \& Hamner 1988; Tynan 1997; Johnston et al. 2005). In another part of this study, Heaviside's dolphins were found to move offshore at night, where they are thought to feed on vertically migrating prey (Sekiguchi et al. 1992), and to spend daylight hours (when the data used in this study were collected) closer to shore resting and not feeding (Elwen et al. 2006). In animals that are not feeding, influences on distribution can be far less clear, but most evidence suggests, that when resting or otherwise unengaged, cetaceans choose environments that are safe, from both predators and harsh environmental conditions (Whitehead \& Moore 1982; Smultea 1994; Elwen \& Best 2003; Lammers 2004; Heithaus \& Dill 2006). Thus, even though Heaviside's dolphins appear not to be feeding while close inshore, they may still exhibit a preference for certain habitat types where predation risk is lower (inshore generally) or conditions are more conducive to resting and socializing.

A further consideration in the ecology of Heaviside's dolphins is potential competition with the slightly larger, sympatric dusky dolphin. The observable consequences of interspecific competition between sympatric predators vary from occasional harassment to potentially devastating influences on the 'weaker' species, such as local extinctions (Creel \& Creel 1996; Linnel \& Strand 2000). Interactions between competing predators might not be obvious and may only be seen as avoidance by the weaker (almost always the physically smaller species, in this case the Heaviside's dolphin) of the stronger species. This may result in habitat differentiation and occasionally the counter-intuitive result of the weaker species having a higher survival rate in areas of lower prey abundance, if these areas act as refuges from competition (Durant 1998; Linnel \& Strand 2000; Thompson et al. 2004). Spatial competitive exclusion of Burmeister's porpoises has been suggested in Golfo San José, Argentina, with porpoises occupying intermediate depths between the preferred ranges of dusky and bottlenose (Tursiops truncatus) dolphins (Goodall et al. 1995). Temporal (and possibly spatial) segregation of harbour porpoises (Phocoena phocoena) and bottlenose dolphins has been observed in areas of the Moray Firth, Scotland (Thompson et al. 2004).

Competition between sympatric cetaceans may be mediated more subtly by resource partitioning including differences in fine-scale habitat selection and prey species taken (Bearzi 2005; Parra et al. 2005; Heinrich 2006). There is some evidence to suggest that the two species in the current study occupy different niches, as they respond to different environmental cues (Elwen et al. 2009) and eat different species and sizes of prey (Sekiguchi et al. 1992) although with a significant amount of overlap.

In this paper we use sightings data gathered during inshore photo-identification surveys to investigate how environmental variables affect the distribution and degree of overlap of Heaviside's and dusky dolphins in the near-shore environment. We further compare the observed patterns of distribution with that of near-shore fishery activity observed during the same period.

\section{METHODS}

\section{Field data}

The spatial data used in this study were not collected specifically to answer questions of distribution and habitat modelling, but were part of a three-year photographic mark-recapture study focused on questions of individual movements and range along the southern west coast of South Africa (Fig. 1). In the first year of the study (1999), effort was restricted to a $20 \mathrm{~km}$-long stretch of coast around Britannia Bay, and in the second and third years of the study (2000 and 2001) the full $\sim 390 \mathrm{~km}$ study area was searched. The goal was to search as much of the coastline within the overall study area as possible. However, due to large distances between safe launching sites and unpredictable weather conditions, effort was higher closer to the harbours from which the research boat was launched (Fig. 2).

All data were collected from a $6 \mathrm{~m}$ rigid inflatable vessel fitted with twin $40 \mathrm{hp}$ outboard motors and an elevated observation platform (putting eyes at about $3 \mathrm{~m}$ a.s.l.). Weather permitting, the boat was launched daily and used to run searches parallel to and just behind the breaker line roughly $0.3-1 \mathrm{~km}$ from shore, where densities of Heaviside's dolphins are known to be highest during the day (P.B.B., pers. obs.). Search speed was 6-8 kn. Upon encounter, dolphins were followed until photog- 

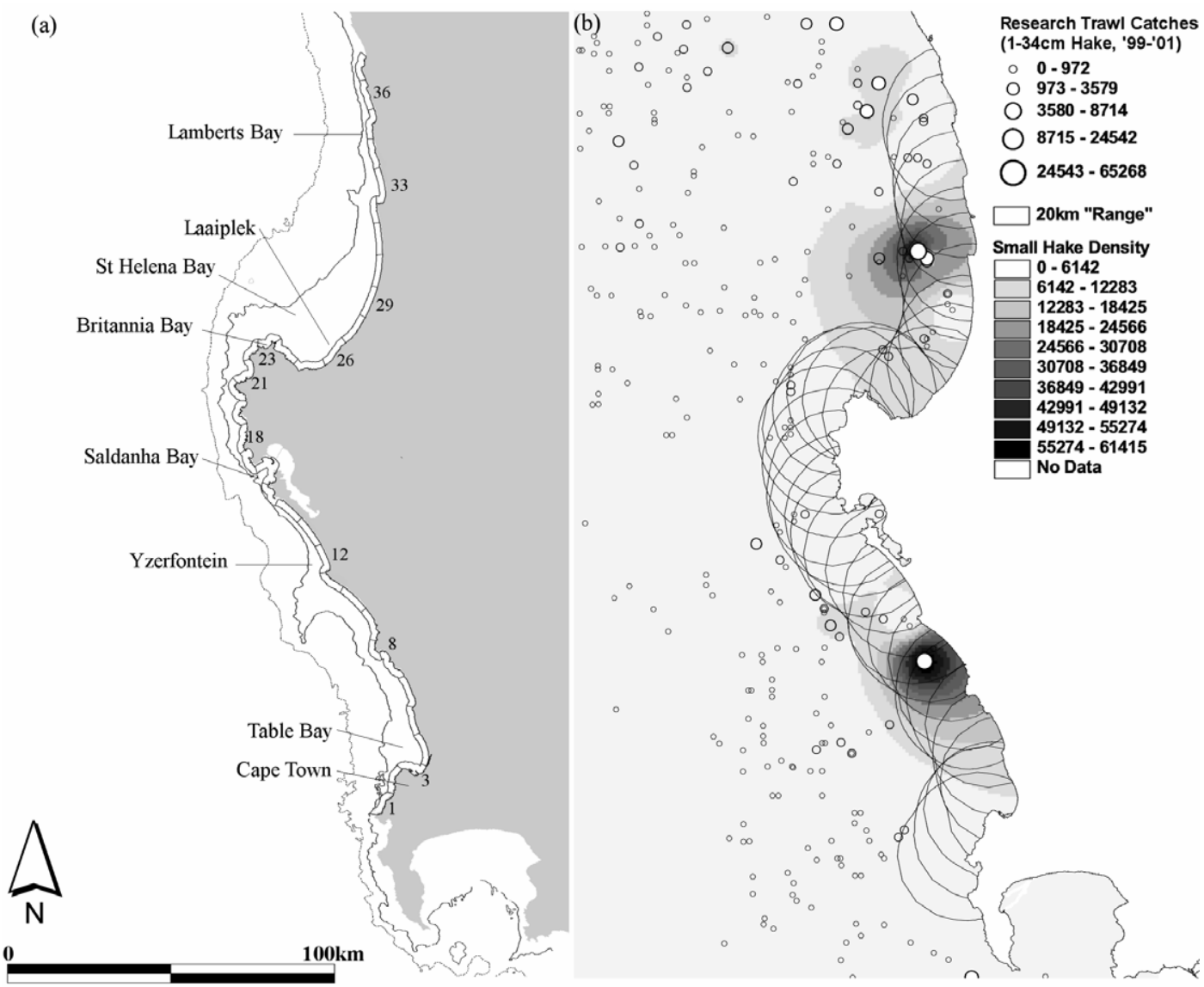

Fig. 1. a, Study area on the southern west coast of South Africa, showing the $10 \mathrm{~km}$-long bins used to define search effort along the coast (numbered from south to north 1-36). b. Interpolated research trawl data of number of small (1-34 cm) shallow-water hake (Merluccius capensis) caught per hour, shown as raw trawl counts (circles) and interpolated values (solid colour) for data from 1990 to 2001 . Overlain on trawl data are the $20 \mathrm{~km}$ 'search ranges' from each $10 \mathrm{~km}$ bin along the coast used to calculate the amount of hake potentially available to dolphins in those bins.

raphy was regarded as complete, or until the dolphins were lost. At each sighting sea-surface temperature (SST), depth (from an onboard fish finder) and GPS position were noted. Maximum, minimum and best group size estimates were noted, as well as group composition (adult or calf). New subgroups of either the same or a different species which joined or approached the focal group within $100 \mathrm{~m}$ were recorded under the same sighting number but noted with an additional subscript. Some individuals and groups were strongly attracted to the boat for bow-riding. To prevent these animals following the boat and being photographed repeatedly, a sustained burst of speed of up to $15 \mathrm{kn}$ was used when necessary, while moving away from a completed group. The offshore limit to the study area (or 'strip width') was defined as the furthest distance offshore of any dolphin sighting made under normal search conditions. This $2 \mathrm{~km}$ wide strip of coast was split into 36 bins, each roughly $10 \mathrm{~km}$ long. This scale created enough variation for differences to be seen, yet was not so small as to have very large variations in search effort. Encounter rates for groups, dolphins and calves per kilometre searched were subsequently calculated for each bin.

\section{Environmental data}

Depth and SST were collected at the site of each dolphin encounter as well as at the start and stop points of each search leg independently of dolphin presence. The measured depth values were combined with data from the digitized 


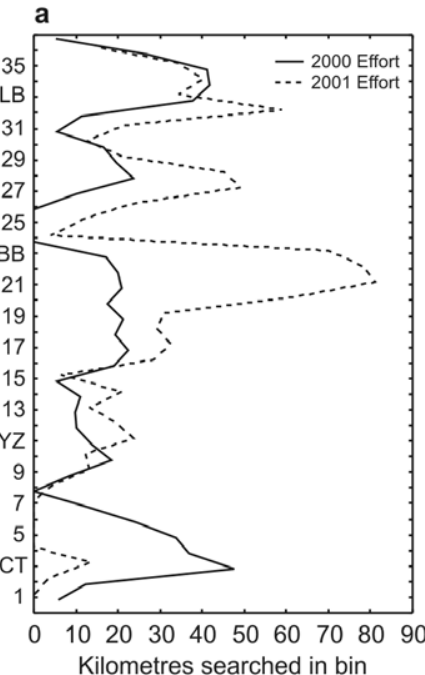

b

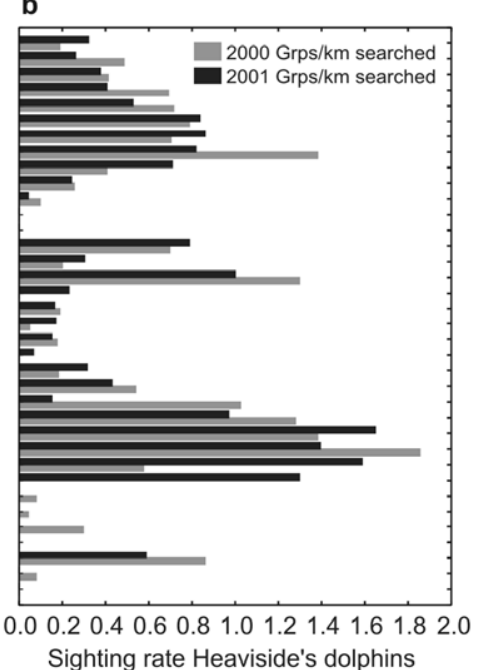

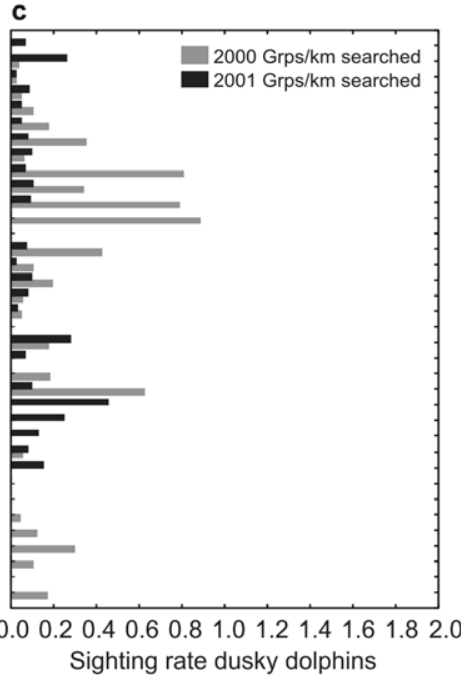

Fig. 2. Figure oriented with north at the top and south at the bottom, with the bins containing Cape Town (CT), Yzerfontein (YZ), Britannia Bay (BB) and Lamberts Bay (LB) shown by letters. a, Number of km searched in each $\sim 10 \mathrm{~km}$-long bin along the southern west coast of southern Africa in 2000 and 2001; b, number of groups of Heaviside's dolphins (Cephalorhynchus heavisidii) seen per km searched in each bin in 2000 and 2001; c, number of groups of dusky dolphins (Lagenorhynchus obscurus) seen per km searched in each bin in 2000 and 2001.

1:150 000 South African Naval Hydrographer's navigation charts for the study region (SAN117-119) and used to build a TIN (a 3D sea floor model) in Arcview GIS 3.3. From this model we estimated the slope of the sea floor at each dolphin sighting and the average slope and depth for large areas. Exposure to swells was calculated using a 12-year average (1990-2001) of data for the square $17-19^{\circ} \mathrm{E}$ by $33-35^{\circ} \mathrm{S}$ collected from voluntary observer ships and kept in the CSIR EMATEK Marclim database (following Elwen \& Best 2003). This average effectively represents the offshore swell climate in the absence of any land to break it up. The majority of swell are off southern Africa originates in the southwest quarter, resulting in the corners of most bays on the south and west coasts being fairly protected, while straight sections of coastline are mostly exposed to open ocean swell. Areas that were protected from more than 30\% of this swell (east of the SSW-NNE line) were regarded as 'partly-protected', while areas protected from more than $60 \%$ of swells (south and east of the WSW-ENE line) were regarded as 'protected'. The shore type along the coast (which can be reasonably assumed to represent the near-shore substrate, Elwen \& Best 2003) was defined following the Coastal Sensitivity Atlas of Southern Africa (Jackson \& Lipschitz 1984). The coastline within the study area consists of four shore types, 'wave cut rocky platforms', 'exposed rocky headlands', 'fine sandy beaches' and 'estuarine'. Since exposed rocky headlands and estuarine shore types composed $<5 \%$ of the shore type we combined these with the predominant rocky and sandy shore types for analysis.

\section{Prey availability data}

Hake catch data for the study area between 1990 and 2001 were available from standardized research trawls for both deep- and shallow-water hake (Merluccius paradoxus and M. capensis, respectively) performed by the Marine and Coastal Management section of the South African Government's Department of Environmental Affairs and Tourism. Of the two species, only the distribution of shallow-water hake overlapped significantly with the known offshore range limits of Heaviside's dolphins (Elwen et al. 2006). Thus we have assumed, although it is not known with certitude (Sekiguchi et al. 1992), that this is the species that Heaviside's dolphins eat. Sekiguchi (1994) gives the average size of hake eaten by Heaviside's dolphins as $19.5 \mathrm{~cm}$, with a range of $12-28 \mathrm{~cm}$. The trawl data split the catches into size/age groups of 1-19, $20-34,35-44 \mathrm{~cm}$, etc., only the two smallest groups were deemed relevant and combined for analysis. Research trawls did not occur in the same places each year and few occurred close to shore, as it 
Table 1. Categories used to describe fishing activity observed within $2 \mathrm{~km}$ of the coast during the collection of photo-identification data on Heaviside's dolphins (Cephalorhynchus heavisidii) off the Western Cape coast, South Africa. Activity differentiated by fishery type.

\begin{tabular}{llll}
\hline Cray fishing & Set netting & Line fishing & Other \\
\hline Traps - unattended & Nets in water - unattended & Kelp gathering \\
Boats associated with traps & $\begin{array}{l}\text { Boats associated with nets } \\
\text { (setting/hauling/hoop } \\
\text { netting)(setting/hauling) }\end{array}$ & $\begin{array}{l}\text { Hand lining/angling from } \\
\text { boats }\end{array}$ & Recreational boats \\
$\begin{array}{l}\text { Transiting boats (presumed } \\
\text { crayfishers) }\end{array}$ & $\begin{array}{l}\text { Transiting boats (presumed } \\
\text { net fishers) }\end{array}$ & $\begin{array}{l}\text { Transiting boats (presumed } \\
\text { line fishers) }\end{array}$ & \\
\hline
\end{tabular}

was the larger hake in deeper water that were of commercial interest. Data from all years were combined to create a long-term average and point trawls (number of fish per trawl standardized to an hour's trawl) were then interpolated using Arcview 3.3 (Fig. 1).

To analyse the interaction between dolphins and their prey we created $20 \mathrm{~km}$ semi-circular arcs around each $10 \mathrm{~km}$ coastal bin, thus establishing a 'home range' for each segment of coast that was up to $50 \mathrm{~km}$ long (coastwise) and $22 \mathrm{~km}$ offshore (including the $2 \mathrm{~km}$ width searched from the coast). This distance fell within the known home range limits of Heaviside's dolphins (Elwen et al. 2006) and did not exceed the observed offshore distribution of the species (Findlay et al. 1992). The amount of hake within each 'range' was calculated to create a measure of potential prey available to a dolphin living in that region. The 'ranges' of adjacent $10 \mathrm{~km}$ bins clearly overlapped with potential auto-correlation problems, but since the ranges of Heaviside's dolphins apparently overlap freely (Elwen et al. 2006), we regarded this to be a reasonable approximation of reality.

It was not possible to include any type of prey distribution data into the spatial analysis of dusky dolphin distribution as similar digitized, inshore research trawl data for horse mackerel (Trachurus trachurus), their predominant prey type in South Africa (Sekiguchi et al. 1992), were unavailable. However, dusky dolphins are more generalist feeders than Heaviside's dolphins locally (and diverse in their feeding strategies across most of the world; Würsig \& Würsig 1980; Cipriano 1992) so even though horse mackerel is the predominant prey type of dusky dolphins, it does not form as large a proportion of their diet as hake does for Heaviside's dolphins, and a close link to a dominant prey distribution is thus less likely to occur.

\section{Potential fishery interactions}

In an effort to gain some understanding of the distribution of fishing effort within the study area and to be able to highlight areas of potential human-dolphin conflict, data were collected on all inshore fisheries and boating activity observed in the area during field work. These were categorized by fishery type and activity (Table 1).

\section{Analysis}

Broad-scale relationships between dolphin sighting rates and environmental variables in the $10 \mathrm{~km}$ bins of coast (average depth and slope, protection from swells and amount of hake potentially available) were investigated using non-parametric correlation. Each year was analysed separately due to differences in effort, and sighting rates per bin were compared between years.

Niche separation between Heaviside's and dusky dolphins was investigated by comparing environmental factors associated with their distribution using a binomial generalized additive model with a logit link function in Programme R. Categorical variables included were shore type (rocky or sandy), swell exposure (protected, partly protected or exposed), moon brightness (less than or more than half full) and region of the coast as $10 \mathrm{~km}$ bins grouped into regions as follows 1(1-8), 2 (9-15), 3 (16-20), $4(21-23), 5(24-26), 6(27-29), 7(30-33)$ and 8 (34-36) to increase sample sizes in areas of low effort. Continuous variables (SST, depth, hake availability) were fitted as smoothed terms. Variation in effort along the coast was accounted for by using the log of $\mathrm{km}$ searched per region as an offset function in the model. The model was not over dispersed and a backwards stepwise alpha-to-enter, alpha-to-exit approach was used to fit parameters.

For a finer-scale investigation of the effects of environmental variables on dolphin groups, the raw sightings data were analysed using a general 

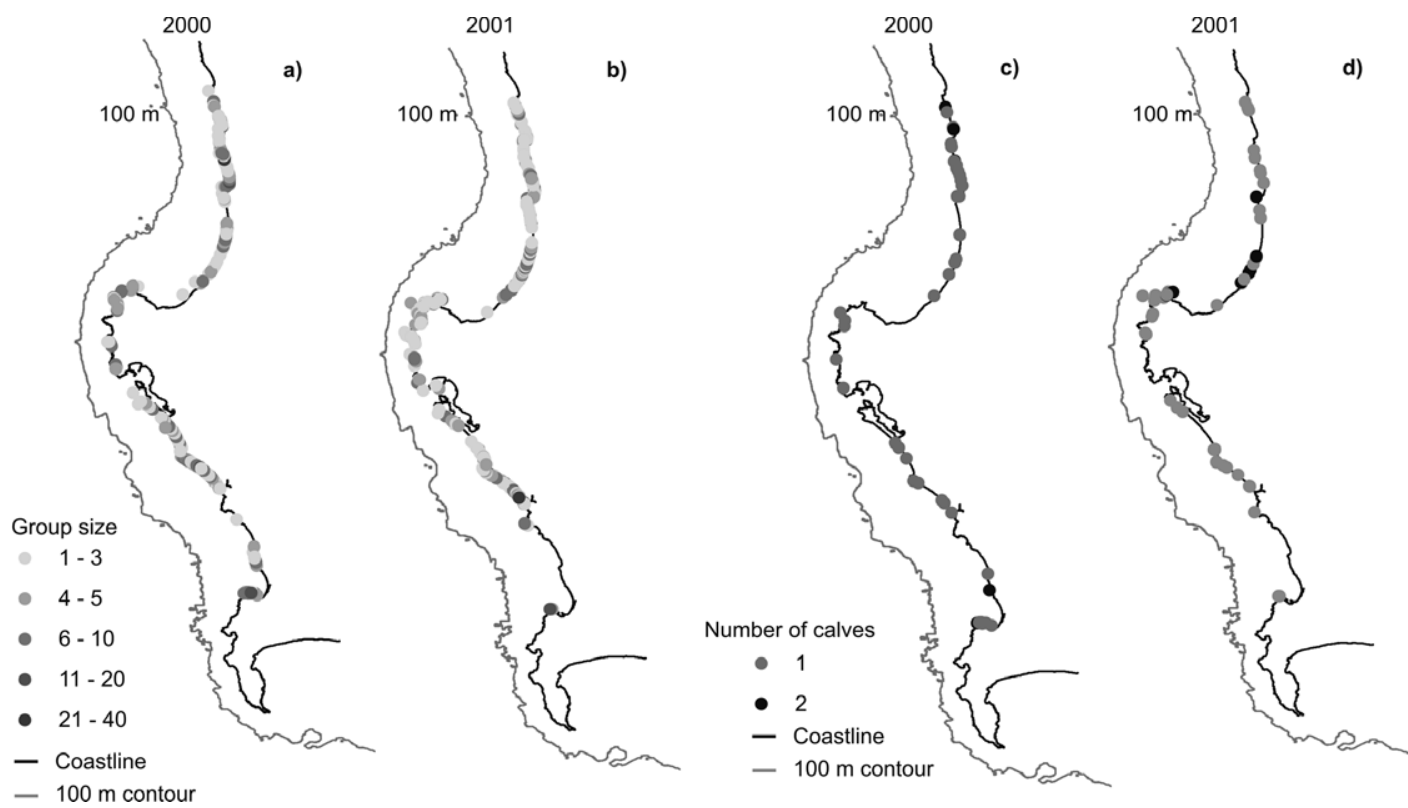

Fig. 3. a, b, Distribution of all Heaviside's dolphins (Cephalorhynchus heavisidii) sightings in 2000 and 2001, respectively; darker colours represent increasing group sizes; $\mathbf{c}, \mathbf{d}$, distribution of groups of Heaviside's dolphins containing calves in 2000 and 2001, respectively.

additive model for both Heaviside's and dusky dolphins separately with a Gaussian distribution and identity link function. The response variable used was the best estimate of group size, as measured in the field with 'zero' data generated by using environmental data measured at the start and stop point of survey tracks. For both species we used a step-wise, alpha-to-enter, alpha-to-exit approach using the same variables as in the binomial approach above.

\section{RESULTS}

Heaviside's dolphins were seen on effectively every day at sea (109 of 110 sea days), dusky dolphins only on 65 of 110 (59.1\%) sea days. Mixed groups and sightings of the two species in close proximity were relatively common. In $30.5 \%$ of 177 sightings of dusky dolphins, groups were seen with or near enough to a group of Heaviside's dolphins to be considered as a single sighting.

The sighting rate of Heaviside's dolphin groups was remarkably similar between 2000 and 2001 and strongly correlated $\left(r^{2}=0.605, P<0.001\right)$ despite varied search effort in each bin and season (Figs $2 \& 3$ ). In both years, all three measures of dolphin density were positively correlated with the amount of juvenile hake potentially available from each bin (Table 2). Bins with high exposure to swells and those with predominantly sandy shores also showed a positive correlation with some measures of sighting rate but differed between years, suggesting that if there is a relationship, it is weak at this scale.

The sighting rates of dusky dolphins were far more variable than those of Heaviside's dolphins (Fig. 2) and did not correlate at all between years $\left(r^{2}=0.02, P=0.44\right)$. However, in both study years, all three sighting rates measured (groups, dolphins and calves seen per $\mathrm{km}$ searched) were significantly positively correlated with the percentage of sandy shore in each bin and in 2000 showed a negative correlation with the amount of hake potentially available offshore (Table 2).

Heaviside's dolphins were generally seen in smaller groups than dusky dolphins (Heaviside's dolphins: mean $=4.53$; mode $=2$; median $=4$; dusky dolphins: mean $=17.15$; mode $=4$; median $=6$ ) which were occasionally seen in very large groups of up to 500 animals. Notably, these large groups of more than 50 animals were only ever seen within St Helena Bay (Fig. 4a,b) from bins 22-29. Dusky dolphins occasionally formed nursery groups (never seen in Heaviside's dolphins), consisting almost exclusively of multiple mother-calf pairs, although calves were also seen in mixed groups, in which adults and juveniles 

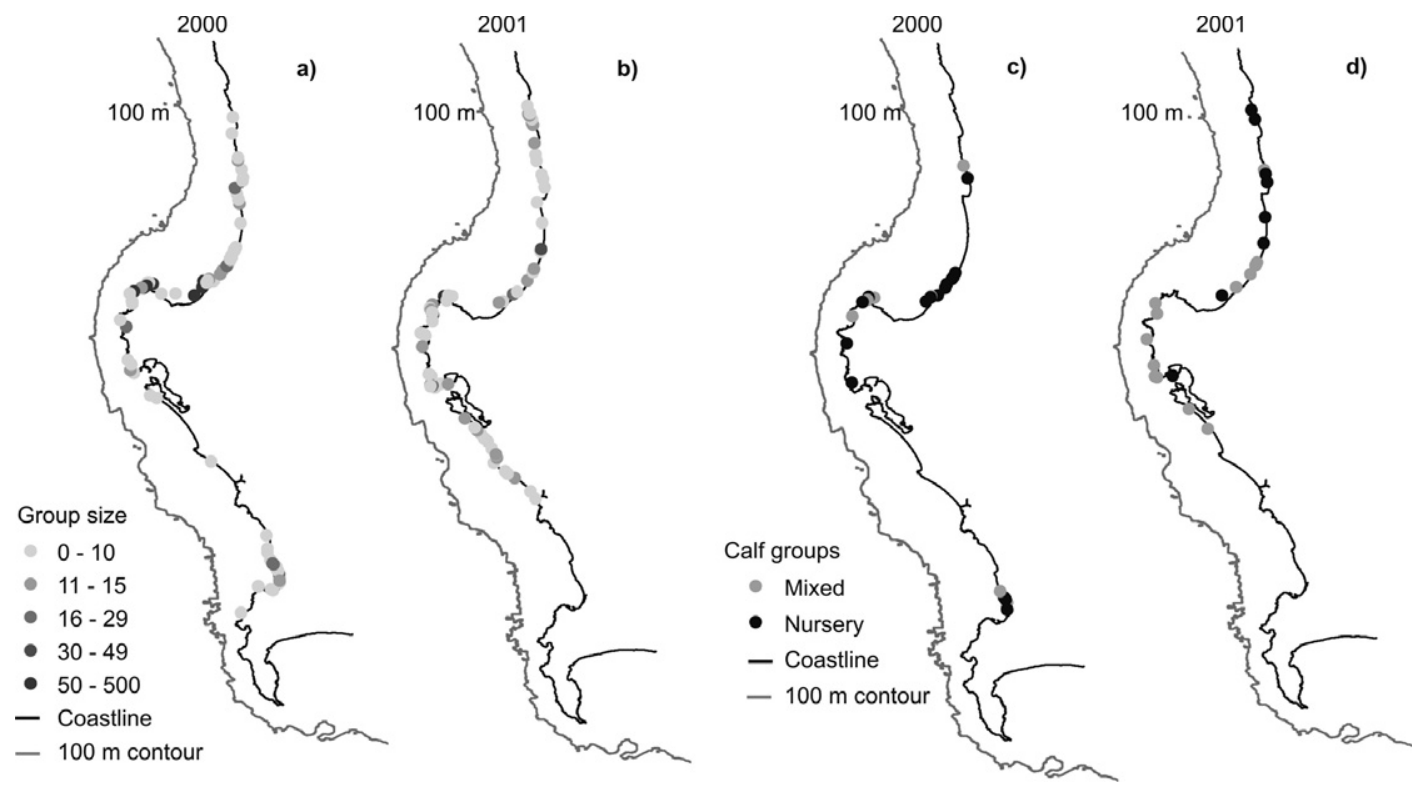

Fig. 4. a, b, Distribution of all dusky dolphin (Lagenorhynchus obscurus) sightings in 2000 and 2001, respectively; darker colours indicate increasing group sizes; $\mathbf{c}, \mathbf{d}$, distribution of the two types of groups containing dusky dolphin calves 2000 and 2001, respectively (mixed groups containing adults, juveniles and calves and nursery groups of mothers and calves only).

significantly outnumbered calves (Fig. 4c,d). Calves were seen throughout the study area and there was no evidence of a nursery region.

In the field, multiple subgroups were often assigned to the same sighting number if new groups approached the boat while one was already being photographed. These subgroups thus had the same environmental data. To avoid replication issues in the model, we used only the first subgroup of each species assigned to a sighting number, leaving 809 sightings of Heaviside's dolphins and 178 sightings of dusky dolphins available for anlaysis.

The binomial model differentiated sightings of the two species based on region, moon brightness, hake availability, sea surface temperature and depth (Table 3). Heaviside's dolphins were found in shallower and cooler water (Fig. 5) and were more likely to be seen during the brighter phase of the moon and in areas where hake availability was higher. The influence of region was mainly driven by the observations in regions 4 and 5, where Heaviside's dolphins and dusky dolphins, respectively were more prevalent. Region 4 included the 1999 study area and Britannia Bay, where Heaviside's dolphins are very common, and region 5 is the protected part of St Helena Bay in which sight- ings of Heaviside's dolphins were very rare.

The Generalized Additive Model developed to investigate factors influencing the observed group sizes of Heaviside's dolphins showed that group size was influenced by depth, shore type, region and moon phase (Table 4). Larger groups were seen closer to shore, in the brighter phase of the moon and in sandy rather than rocky areas of the coast. As in the previous analysis, the influence of 'region' on this model was driven mainly by the low sample size and small groups seen in region 5 (St Helena Bay).

The most parsimonious Generalized Additive Model of dusky dolphin encounters developed, showed that only hake availability and shore type significantly influenced group size (Table 5). Dusky dolphin groups were larger in areas of sandy shores and lower hake availability. Since hake availability showed a clear spatial pattern (Fig. 1) we investigated the interaction between region and hake in the model, but it was not significant.

\section{Potential cetacean-fisheries conflicts}

Fishing effort tended to cluster around the launch sites available at harbours along the coast, and at all levels was considerably higher north of 
Table 2. Spearman rank correlations between sighting rates of Heaviside's dolphins (Cephalorhynchus heavisidii) and dusky dolphins (Lagenorhynchus obscurus) as the number of groups, dolphins and calves seen per km searched and the environmental variables in each $\sim 10 \mathrm{~km}$ block of coast ( $n=36$ blocks). $R$ values with asterisk are significant at the $5 \%$ level (Statistica 7.0).

\begin{tabular}{|c|c|c|c|c|c|c|}
\hline & $\begin{array}{l}\% \text { Exposed } \\
\text { coast }\end{array}$ & $\begin{array}{c}\% \text { Partly exposed } \\
\text { coast }\end{array}$ & Average slope & Average depth & $\%$ Sandy shore & $\begin{array}{c}\text { Available } \\
\text { hake }\end{array}$ \\
\hline \multicolumn{7}{|c|}{ Heaviside's dolphins 2000} \\
\hline Groups & 0.144 & -0.057 & -0.094 & -0.043 & $0.452^{*}$ & $0.390^{*}$ \\
\hline Dolphins & 0.121 & -0.031 & -0.069 & -0.052 & $0.418^{*}$ & $0.344^{*}$ \\
\hline Calves & 0.330 & -0.225 & 0.011 & -0.097 & 0.266 & $0.424^{*}$ \\
\hline \multicolumn{7}{|c|}{ Heaviside's dolphins 2001} \\
\hline Groups & $0.356^{*}$ & -0.193 & -0.228 & 0.028 & 0.311 & $0.577^{*}$ \\
\hline Dolphins & 0.324 & -0.151 & -0.272 & -0.035 & 0.321 & $0.519^{*}$ \\
\hline Calves & 0.252 & -0.161 & -0.227 & 0.050 & 0.138 & $0.400^{*}$ \\
\hline \multicolumn{7}{|c|}{ Dusky dolphins 2000} \\
\hline Groups & -0.124 & 0.232 & -0.180 & -0.136 & $0.397^{\star}$ & -0.315 \\
\hline Dolphins & -0.136 & 0.269 & -0.224 & -0.213 & $0.390^{*}$ & $-0.351^{*}$ \\
\hline Calves & -0.204 & $0.347^{*}$ & -0.285 & $-0.393^{*}$ & $0.332^{*}$ & $-0.339^{*}$ \\
\hline \multicolumn{7}{|c|}{ Dusky dolphins 2001} \\
\hline Groups & 0.231 & -0.046 & 0.046 & -0.028 & $0.394^{*}$ & 0.197 \\
\hline Dolphins & 0.079 & 0.085 & -0.078 & -0.157 & $0.471^{*}$ & 0.013 \\
\hline Calves & -0.017 & 0.085 & -0.089 & -0.107 & $0.360^{*}$ & -0.181 \\
\hline
\end{tabular}

Saldanha Bay than between Cape Town and Saldanha Bay (Fig. 6); this is largely due to the distribution of the (mostly subsistence) fishermen themselves.

Crayfish trapping and hoop-netting activity was seen in both years in bins 18 (just north of Danger Bay) and 22 (Seal Rocks) but the most extensive crayfishing occurred in the Lamberts Bay region, where set traps were regularly seen close to shore (the highest number of trap-buoys counted was 60 in one location). Set nets and their associated boats were primarily seen in two regions, very near to the Yzerfontein harbour mouth and around block
26 (just north of the Laaiplek harbour in the Berg River mouth), which consisted mainly of a St Joseph's shark (Callorhinchus capensis) fishery. Currently, the fishery in this area is felt to be potentially the most threatening to Heaviside's dolphins due to the high number of nets with a large mesh size. Of great concern is the high number of illegal set nets in the area, principally used to catch smooth hound sharks (Mustelus mustelus); these nets are often 400-700 m long, up to 10 per boat and sunk beneath the surface and often set for a day or more (Steven Lamberth, Marine and Coastal Management, pers. comm.).

Table 3. Results of the best habitat model (binomial GAM with logit link and search effort fitted as an offset) investigating which environmental factors influenced the distribution of Heaviside's (Cephalorhynchus heavisidii) and dusky dolphin (Lagenorhynchus obscurus) on the west coast of South Africa between 1999 and 2001.

\begin{tabular}{lllll}
\hline Categorical terms & E.D.F. & D.F. & $\chi^{2}$ & $P$-value \\
\hline Region & & 7 & 89.61 & 0.0016 \\
Moon & & 1 & 10.34 & 0.0013 \\
\hline Smoothed terms & & & & \\
\hline Hake & 1.0 & 1.50 & 6.86 & 0.0183 \\
SST & 3.984 & 4.48 & 22.33 & 0.0003 \\
Depth & 1.0 & 1.5 & 8.46 & 0.0078 \\
\hline
\end{tabular}



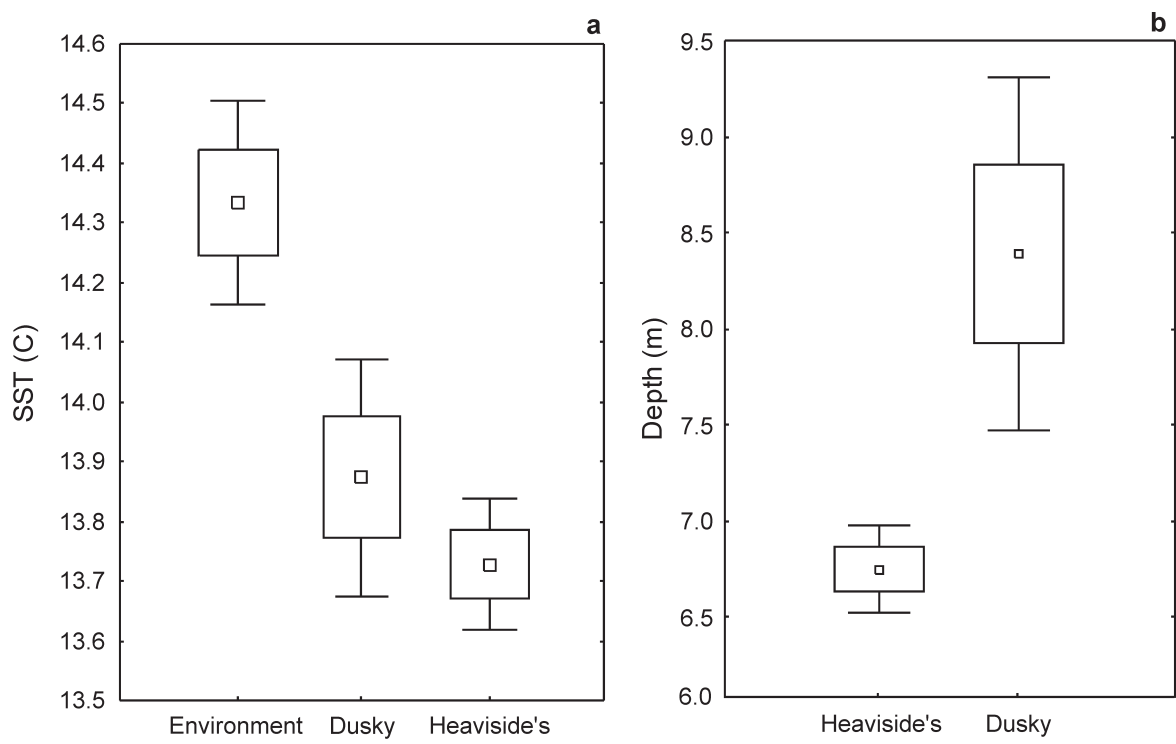

Fig. 5. Box plots (point: mean, box: S.E., whiskers: 1.96 S.E.) showing (a) the mean sea surface temperature in the environment generally and at sightings of Heaviside's (Cephalorhynchus heavisidii) and dusky dolphins (Lagenorhynchus obscurus) and (b) the mean depth measured the beginning of each dolphin sighting.

Mortalities of cetaceans and sea birds in these nets are thought to be high, but are currently unquantified.

During the three seasons of field work involved in this project, only one dolphin entrapment was observed. At Yzerfontein harbour two Heaviside's dolphins swam rapidly toward our research vessel as its engines were started upon launching, and became entangled in a short set net just outside the harbour. The accompanying fishermen released both animals alive within minutes.

\section{DISCUSSION}

Our data show that the inshore density of Heaviside's dolphins varied along shore within their overall range but was spatially consistent between the two years of the study. Heaviside's dolphins were seen more regularly in regions where juvenile hake is consistently more abundant immediately offshore and to a lesser extent, more in areas with sandier shores and higher exposure to swells.

The data on the distribution and behaviour of shallow-water hake are limited nearshore, due to the commercial and scientific interest being primarily in the bigger animals further from shore. However, the two areas of higher hake density highlighted in this study (approximately off Lamberts Bay and Yzerfontein) are also obvious in Payne's (1989) figure of the distribution of all shallow-water hake made using a similar but older data set to the one in this study. No published explanation for these apparent hotspots in hake numbers can be found. However, the southern Benguela Current system

Table 4. Results of best habitat model (Generalized Additive Model with Gaussian fit and Identity link function, with search effort fitted as an offset) relating environmental factors to Heaviside's dolphin (Cephalorhynchus heavisidii) group size on the west coast of South Africa, 1999-2001.

\begin{tabular}{lcccc}
\hline Categorical terms & E.D.F. & D.F. & $\chi^{2}$ & $P$-value \\
\hline Shore & 1 & 4.486 & 0.034 \\
Region & 7 & 2.717 & 0.008 \\
Moon & 1 & 7.592 & 0.006 \\
\hline
\end{tabular}

Smoothed terms

\begin{tabular}{lllll}
\hline Depth & 2.063 & 2.563 & 15.3 & $<0.0001$
\end{tabular}


Table 5. Results of bets habitat model (Generalized Additive Model with Gaussian fit and Identity link function, with search effort fitted as an offset) relating environmental factors to dusky dolphin (Lagenorhynchus obscurus) group size on the west coast of South Africa, 1999-2001.

\begin{tabular}{lcccc}
\hline Categorical terms & E.D.F. & D.F. & $\chi^{2}$ & $P$-value \\
\hline Shore & & 1 & 10.82 & 0.00109 \\
\hline Smoothed terms & & & & \\
\hline Hake & 1 & 1.5 & 7.515 & \\
& 0.00196 & & & \\
\hline
\end{tabular}

is a wind-driven upwelling current system in which changes in bottom topography and longshore wind stress can result in locally enhanced and predictable upwelling cells (Pitcher et al. 1992). Two of the strongest upwelling cells in the region occur off the Cape Peninsula and Cape
Columbine, roughly $60 \mathrm{~km}$ to the south of the observed 'hot spots' at Yzerfontein and Lamberts Bay, respectively. It is feasible that the higher density of dolphins and hake in these areas is related to the downstream enrichment of the environment associated with these upwelling

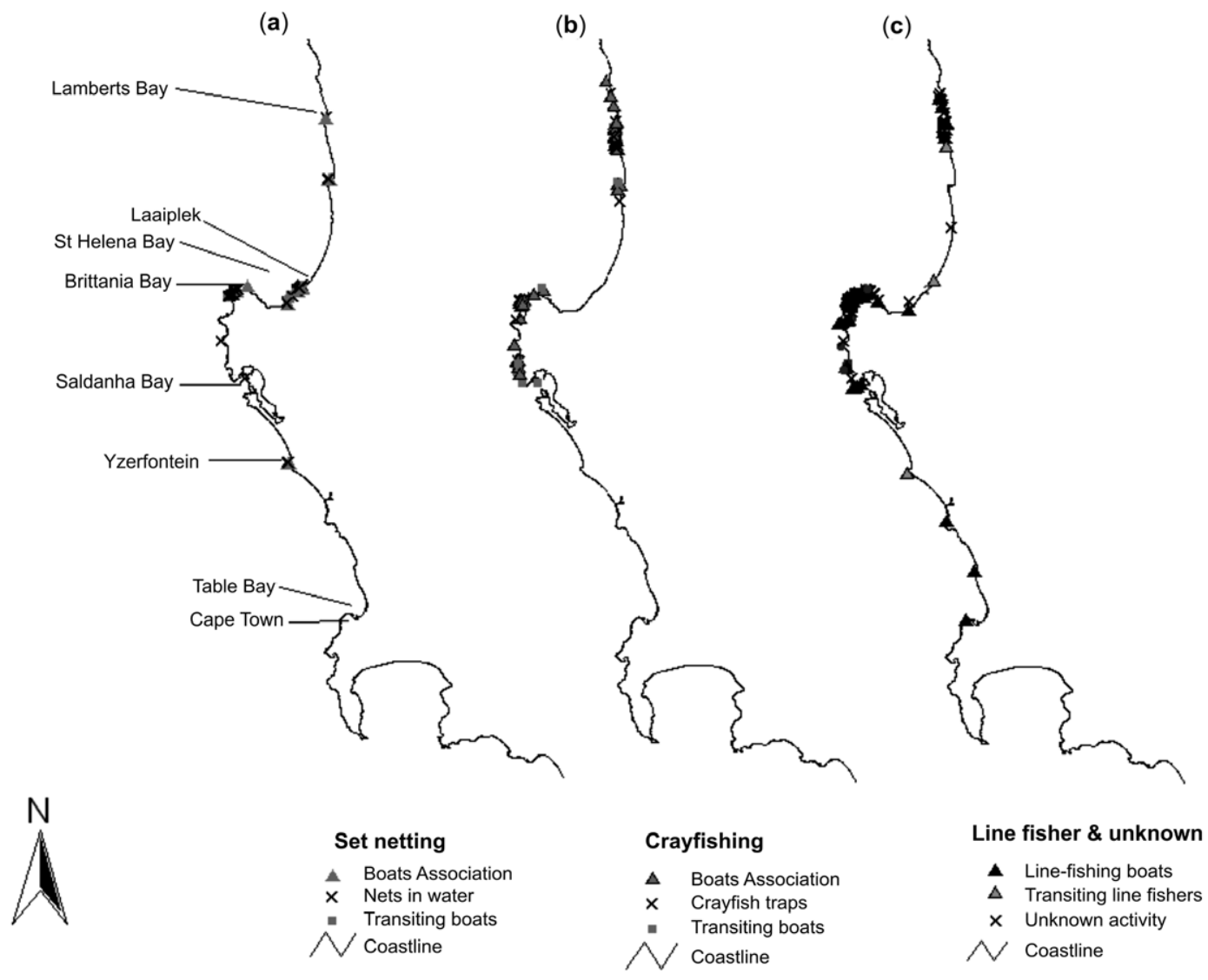

\section{0}

Fig. 6. Maps showing the distribution of fishing effort as boats and traps/nets as observed during field work during 1999-2001. Data split by fishery into (a) set netting, (b) crayfishing, and (c) line fishing and unknown vessel operations. 
cells. The close spatial association between Heaviside's dolphins and shallow-water hake highlighted in this study is reflected in the strong diurnal migration patterns of Heaviside's dolphins observed from shore (Elwen et al. 2009) and seen in the results of satellite telemetry (Elwen et al. 2006). The offshore movement of Heaviside's dolphins in the late afternoon is thought to be related to nocturnal feeding on prey (juvenile hake) that migrates closer to the surface at night when visually hunting predators are less effective (Elwen et al. 2009). The brightness of the moon is thought to affect the vertical migration patterns of fish (Woodhead 1966) such that they remain deeper and are thus less available to predators during periods of brighter light conditions. The findings of this study suggest that Heaviside's dolphin group sizes are slightly higher during periods with a brighter moon, while sighting rates observed from shore are also higher during similar periods (Elwen et al. 2009). Both findings indicate relatively subtle shifts in the overall behaviour of the animals but certainly suggest that changes in the type or availability of prey offshore are enough to cause shifts in the foraging strategies used by Heaviside's dolphins, such as by group size or time spent offshore. Shallow-water hake is considerably more common in Namibian waters (Payne 1989) than in South African waters and a comparison of Heaviside's dolphin diets, distribution and movement patterns in the two areas would be informative.

The distribution patterns of small cetaceans along the west coast of South Africa have previously only been studied at broad spatial scales and further from shore (Findlay et al. 1992). The findings of this study confirm the near-continuous distribution of Heaviside's dolphins in the inshore environment. Bays on the west coast of South Africa are given their shape by the predominant south-westerly swell, which results in their generally having an exposed open end with larger swell to the north and a protected corner in the south (Bremner 1991). Observations of Heaviside's dolphins were considerably more frequent at the exposed end of bays, where the swell was large, and dolphins were often first sighted while exiting the back of waves and heading toward the boat at high speed to bow-ride it. The only areas of predictably low density were the most protected areas of water along the coast at St Helena and Saldanha Bays, which have almost no swells in summer months. However, these areas of low density are smaller than the known home range size of the species (Elwen et al. 2006) and are unlikely to represent real discontinuities in the species' distribution. Indeed, Heaviside's dolphin shows little phylogeographic population structure (Jansen van Vuuren et al. 2002). This pattern contrasts with the closely related Hector's dolphin of New Zealand that has a distinctly patchy distribution throughout its range which, combined with very limited dispersal, has resulted in distinct genetic differences between populations as little as $500 \mathrm{~km}$ apart (Pichler et al. 1998). The relative straightness of the west coast of southern Africa, in comparison with the New Zealand coastline, might be a contributing factor to the differences in the range of these two closely related species. Habitat openness (straight coastline or protected inlets) has been linked with home range size in delphinids, with dolphins in more open habitats (Defran et al. 1999) ranging considerably further than dolphins in more closed, estuarine or coastal island type habitats (Gubbins 2002; Heinrich 2006). From a conservation perspective, the more continuous distribution and low genetic differentiation of the Heaviside's dolphin makes it potentially more resilient than the Hector's dolphin, populations of which are known to be at serious risk due to anthropogenic factors (e.g. Slooten \& Lad 1991; Slooten et al. 1992).

Dusky dolphins were not the focal species of this study and were seen less frequently than Heaviside's dolphins, although in larger groups. Within the study area, dusky dolphins had a less predictable distribution pattern than Heaviside's dolphins; sighting rate varied considerably along the coast and was not similar between years. The observed patterns suggest a general preference for areas with sandy rather than rocky shores. However, the range of dusky dolphins extends further from shore than that of Heaviside's dolphins (Findlay et al. 1992). Thus, sightings occurring very close to shore as in this study are effectively at the edge of their range and relationships observed may not be fully representative of the overall habitat choices of the species, so these patterns must be interpreted with caution.

The most striking feature in the distribution of dusky dolphins was the occurrence of very large groups of 50-500, which were limited to the St Helena Bay region. Dusky dolphins are known to use a variety of feeding strategies that reflect in their group sizes and movement patterns. In Peninsula Valdez, Argentina, for instance, several medium-size groups of dolphins aggregate to 
form very large groups (20-300) while surfacefeeding on schools of anchovy (Engraulis anchoita) in summer, but such large groups are far rarer during winter when the anchovy moves offshore (Würsig \& Würsig 1980). At Kaikoura Canyon, New Zealand, dusky dolphins form much larger groups in winter and remain offshore and feed all day, while in summer they show a pronounced onshore-offshore movement pattern and feed nocturnally in small groups on animals associated with the deep scattering layer (Benoit-Bird et al. 2004; Markowitz 2004). Different predation strategies are also evident from dusky dolphins in South Africa, where analysis of stomach contents strongly suggests that alternate feeding strategies do exist, with animals apparently feeding on fish associated with either the pelagic, mesopelagic or inshore environments at any given time (Best 2007). The large groups observed in the St Helena Bay area may be aggregations associated with surface feeding on schooling fish in a similar manner to that observed in Argentina (Würsig \& Würsig 1980).

St Helena Bay is very close to the site of a strong, regular upwelling plume enriching the area (Pitcher et al. 1992). Shore based observations in the same area showed that dusky dolphins moved offshore during windy conditions that were likely to cause upwelling (Elwen et al. 2009). We do not know if the prey species being taken by dolphins in these upwelling areas were different to those in non-upwelling areas, but schooling fish, such anchovy (Engraulis capensis) and sardines (Sardinops sagax), do form a part of the dusky dolphin diet in the study area.

Competition between sympatric species may be mediated by resource partitioning, spatial heterogeneity (Chesson 1985), or competitive exclusion (Durant 1998). The data presented in this study do not allow us to fully investigate the ecological interaction between Heaviside's and dusky dolphins. However, it is clear that some degree of prey partitioning occurs (Sekiguchi et al. 1992), as well as some differentiation in habitat use, primarily depth, distance from shore, water temperature and areas of higher abundance. These mechanisms may be sufficient to mediate any direct inter-specific competition. Currently we can only conclude that, at least in inshore waters where feeding of Heaviside's dolphins is apparently limited, the two species are neither obviously avoiding nor attracted to each other and interactions are generally neutral.

Bycatch in inshore set-netting is the principal concern for Heaviside's dolphin conservation. Within the study area, netting was observed to occur mainly around Yzerfontein (block 12) and just north of Laaiplek. Eighty fishermen hold rights to set nets between Cape Columbine and just north of Laaiplek, but it is the illegal fishery that is currently of most concern. While the potential negative impacts of fisheries on Heaviside's and dusky dolphins appear to be limited within the study area, a reliable estimate of this bycatch is still elusive. Future research should focus on this problem and on obtaining further information on the populations' ability in the Western Cape to withstand any anthropogenic mortality.

\section{ACKNOWLEDGEMENTS}

The authors would like to thank the Institute for Maritime Technology in Simonstown for the digitized bathymetric data, Frances le Clus of DEAT Marine and Coastal Management for the data on hake. These data could not have been collected without the aid of the Earthwatch Institute volunteers who put in many long hours searching for dolphins: C. Bainton, J. de Jarnette, A. Evans, J. Leishmann, T. Pusser, B. Schwarz, S. Dillon, P. Foster, P. Jordan, A. du Sold, S. Einarsson, L. Heidler, J. Bishop, D. Blandford, H. Waite, R. Aiton, J. Chriest, C. Dickens, G. Hayward, K. Martin, A. Rees, J. Culf, U. Daniels, J. Decosta, B. Brown, T. Goodley, R. Johnson, K. Swann, L. Tiller, J. Cheetham, G. Clarke, D. Hawker, B. Lee, J. Thompson, J. Wittrock, C. Blackwell, R. Sparrow, $\mathrm{K}$. Thomson, T. Thomson. This article is based on work supported by the National Research Foundation (South Africa) under grant number 2034991.

\section{REFERENCES}

BEARZI, M. 2005. Dolphin sympatric ecology. Marine Biology Research 1: 165-175.

BEGON, M., TOWNSEND, C.R. \& HARPER, J.L. 2005. Ecology: from Individuals to Ecosystems. Blackwell Publishing, Malden, MA.

BENOIT-BIRD, K.J. \& AU, W.L. 2003. Prey dynamics affect foraging by a pelagic predator (Stenella longirostris) over a range of spatial and temporal scales. Behavioural Ecology and Sociobiology 53:364-373.

BENOIT-BIRD, K.J., WÜRSIG, B. \& McFADDEN, C.J. 2004. Dusky dolphin (Lagenorhynchus obscurus) foraging in two different habitats: active acoustic detection of dolphins and their prey. Marine Mammal Science 20(2): 215-231.

BEST, P.B. 2007. Whales and Dolphins of the Southern African Subregion. Cambridge University Press, Cape Town, South Africa.

BREMNER, J.M. 1991. Logarithmic spiral beaches with 
emphasis on Algoa Bay. In: Algoa Bay - Marine Geoscientific Investigations, (eds) J.M. Bremner, A. Du Plessis, J.G.K. Glass \& R.W. Day. Bulletin of the Geological Survey of South Africa 100: 147-164.

CHESSON, P. 1985. Coexistence of competitors in spatially and temporally varying environments: a look at the combined effects of different forms of variability. Theoretical Population Biology 123: 263-287.

CIPRIANO, F. 1992. Behavior and occurrence patterns, feeding ecology, and life history of dusky dolphins (Lagenorhynchus obscurus) off Kaikoura, New Zealand. Ph.D. dissertation, University of Arizona, Tucson.

CREEL, S. \& CREEL, N.M. 1996. Limitation of African wild dogs by competition with larger carnivores. Conservation Biology 10(2): 526-538.

DAVIS, R.W., FARGION, G.S., MAY, N., LEMING, T.D., BAUMGARTNER, M., EVANS, W.E., HANSEN, L.J. \& MULLIN, K. 1998. Physical habitat of cetaceans along the continental slope in the north-central and western Gulf of Mexico. Marine Mammal Science 14(3): 490-507.

DEFRAN, R.H., WELLER, D.W., KELLY, D.L. \& ESPINOSA, M.A. 1999. Range characteristics of Pacific coast bottlenose dolphins (Tursiops truncatus) in the Southern California Bight. Marine Mammal Science 15: 381-393.

DURANT, S.M. 1998. Competition refuges and coexistence: an example from Serengeti carnivores. Journal of Animal Ecology 67: 370-386

ELWEN, S.H. \& BEST, P.B. 2003. Environmental factors influencing the distribution of southern right whales (Eubalaena australis) on the south coast of South Africa I: Broad scale patterns. Marine Mammal Science 20(3): 567-582.

ELWEN, S.H., MEŸER, M.A, BEST, P.B, KOTZE, P.G.H, THORNTON, M. \& SWANSON, S. 2006. Range and movements of female Heaviside's dolphins Cephalorhynchus heavisidii as determined by satellite telemetry. Journal of Mammalogy 87(5): 866-877.

ELWEN, S., BEST, P., REEB, D. \& THORNTON, M. 2009. Near-shore diurnal movements and behaviour of Heaviside's dolphins (Cephalorhynchus heavisidii), with some comparative data for dusky dolphins (Lagenorhynchus obscurus). South African Journal of Wildlife Research 39(2):100-102

FINDLAY, K.P., BEST, P.B., ROSS, G.J.B. \& COCKROFT, V.G. 1992. The distribution of small odontocetes cetaceans off the coasts of South Africa and Namibia. In: Benguela Trophic Functioning, (eds) A.I.L Payne, K.H Brink, K.H. Mann \& R. Hillborn. South African Journal of Marine Science 12: 237-270.

GOODALL, R.N.P., WÜRSIG, B., WÜRSIG, M., HARRIS, G \& NORRIS, K.S. 1995. Sightings of Burmeisters porpoise, Phocoena spinipinnus, off southern South America. In: Biology of the Phoecenids, (eds) A. Borge \& G.P. Donovan. Reports of the International Whaling Commission, Special Issue 16: 297-316. Cambridge.

GUBBINS, C. 2002. Use of home ranges by resident bottlenose dolphins (Tursiops truncatus) in a South Carolina Estuary. Journal of Mammalogy 83(1): 178-187.

HASTIE, G.D., SWIFT, R.J., SLESSER, G., THOMPSON, P.M. \& TURRELL, W.R. 2005. Environmental models for predicting oceanic dolphin habitat in the Northeast Atlantic. ICES Journal of Marine Science 62: 760770 .
HEINRICH, S. 2006. Ecology of Chilean dolphins and Peale's dolphins at Isla Chiloé, southern Chile. Ph.D. dissertation, University of St Andrews, Scotland.

HEITHAUS, M.R. \& DILL, L.M. 2006. Does tiger shark predation risk influence foraging habitat use by bottlenose dolphins at multiple spatial scales? Oikos 114: 257-264.

JACKSON, L.F. \& LIPSCHITZ, S. 1984. Coastal Sensitivity Atlas of Southern Africa 1984. Department of Transport, Pretoria.

JANSEN VAN VUUREN, B., BEST P.B. \& ROBINSON, T.J. 2002. Phylogeographic population structure of Heaviside's dolphin (Cephalorhynchus heavisidii): conservation implications. Animal Conservation 5: 303-307.

JOHNSTON, D.W., WESTGATE, A.J. \& READ, A.J. 2005. Effects of fine-scale oceanographic features on the distribution and movements of harbour porpoises Phocoena phocoena in the Bay of Fundy. Marine Ecology Progress Series 295: 279-293.

LAMMERS, M.O. 2004. Occurrence and behavior of Hawaiian spinner dolphins (Stenella longirostris) along Oahu's leeward and south shores. Aquatic Mammals 30(2): 237-250.

LINNEL, J.D.C. \& STRAND, O. 2000. Interference interactions, co-existence and conservation of mammalian carnivores. Biodiversity Research - Diversity and Distributions 6: 169-176.

MARKOWITZ, T.M. 2004. Social organization of the New Zealand dusky dolphin. Ph.D. dissertation, Texas A\&M University, Texas, U.S.A.

PARRA, G.J., CORKERON, P.J. \& MARSH, H. 2005. Population sizes, site fidelity and residence patterns of Australian snubfin and Indo-Pacific humpback dolphins: implications for conservation. Biological Conservation 129: 167-180.

PARRA, G.J. 2006. Resource partitioning in sympatric delphinids: space use and habitat preferences of Australian snubfin and Indo-Pacific humpback dolphins. Journal of Animal Ecology 75: 862-874

PAYNE, A.I.L. 1989. The Cape hakes. In: The Oceans of Life off Southern Africa, (eds) A.I.L. Payne \& R.J.M. Crawford. Vlaeberg Publishers, Halfway House, South Africa.

PICHLER, F.B., DAWSON, S.M., SLOOTEN, E. \& BAKER, C.S. 1998. Geographic isolation of Hector's dolphin populations described by mitochondrial DNA sequences. Conservation Biology 12(3): 676-682.

PITCHER, G.C., BROWN, P.C. \& MITCHELL-INNES, B.A. 1992. Spatio-temporal variability of phytoplankton in the southern Benguela upwelling system. In: Benguela Trophic Functioning, (eds) A.I.L Payne, K.H Brink, K.H. Mann \& R. Hillborn. South African Journal of Marine Science 12: 439-456.

SEKIGUCHI, K., KLAGES, N.T.W. \& BEST, P.B. 1992. Comparative analysis of the diets of smaller odontocete cetaceans along the coast of Southern Africa. In: Benguela Trophic Functioning, (eds) A.I.L Payne, K.H Brink, K.H. Mann \& R. Hillborn. South African Journal of Marine Science 12: 843-861.

SEKIGUCHI, K. 1994. Studies on feeding habits and dietary analytical methods for the smaller odontocete species along the southern African coast. Ph.D. thesis, University of Pretoria, Pretoria. 
SLOOTEN, E. \& LAD, F. 1991. Population biology and conservation of Hector's dolphins. Canadian Journal of Zoology 69: 1701-1707.

SLOOTEN, E., DAWSON, S.M. \& LAD, F. 1992. Survival rates of photographically identified Hector's dolphins from 1984-1988. Marine Mammal Science 8: 327-343.

SMULTEA, M.A. 1994. Segregation by humpback whale (Megaptera novaeangliae) cows with a calf in coastal habitat near the island of Hawaii. Canadian Journal of Zoology 72: 805-811.

THOMPSON, P.M, WHITE, S. \& DICKSON, E. 2004. Co-variation in the probability of sighting harbour porpoises and bottlenose dolphins. Marine Mammal Science 20(2): 322-328.

TYNAN, C.T. 1997 Cetacean distributions and oceano- graphic features near the Kerguelen Plateau. Geophysical Research Letters 24(22): 2793-2796.

WHITEHEAD, H. \& MOORE, M.J. 1982. Distribution and movements of West Indian humpback whales in winter. Canadian Journal of Zoology 60: 2203-2211.

WOLANSKI, E. \& HAMNER, W.M. 1988. Topographically controlled fronts in the ocean and their biological influence. Science 241: 177-181.

WOODHEAD, P.M.J. 1966. The behaviour of fish in relation to light in the sea. Oceanography and Marine Biology. An Annual Review 4: 337-403.

WÜRSIG, B. \& WÜRSIG, M. 1980. Behaviour and ecology of the dusky dolphin, Lagenorhynchus obscurus, in the South Atlantic. Fishery Bulletin 77(4): 871-890. 